\title{
Blood warming, pump heating and haemolysis in low- flow extracorporeal life support; an in vitro study using freshly donated human blood
}

Citation for published version (APA):

Kusters, R. W. J., Simons, A. P., Lance, M. D., Ganushchak, Y. M., Bekers, O., \& Weerwind, P. W. (2017). Blood warming, pump heating and haemolysis in low-flow extracorporeal life support; an in vitro study using freshly donated human blood. Perfusion, 32(1), 27-34.

https://doi.org/10.1177/0267659116656045

Document status and date:

Published: 01/01/2017

DOI:

10.1177/0267659116656045

Document Version:

Publisher's PDF, also known as Version of record

Document license:

Taverne

Please check the document version of this publication:

- A submitted manuscript is the version of the article upon submission and before peer-review. There can be important differences between the submitted version and the official published version of record.

People interested in the research are advised to contact the author for the final version of the publication, or visit the DOI to the publisher's website.

- The final author version and the galley proof are versions of the publication after peer review.

- The final published version features the final layout of the paper including the volume, issue and page numbers.

Link to publication

\footnotetext{
General rights rights.

- You may freely distribute the URL identifying the publication in the public portal. please follow below link for the End User Agreement:

www.umlib.nl/taverne-license

Take down policy

If you believe that this document breaches copyright please contact us at:

repository@maastrichtuniversity.nl

providing details and we will investigate your claim.
}

Copyright and moral rights for the publications made accessible in the public portal are retained by the authors and/or other copyright owners and it is a condition of accessing publications that users recognise and abide by the legal requirements associated with these

- Users may download and print one copy of any publication from the public portal for the purpose of private study or research.

- You may not further distribute the material or use it for any profit-making activity or commercial gain

If the publication is distributed under the terms of Article $25 \mathrm{fa}$ of the Dutch Copyright Act, indicated by the "Taverne" license above, 


\title{
Blood warming, pump heating and haemolysis in low-flow extracorporeal life support; an in vitro study using freshly donated human blood
}

\author{
RWJ Kusters,' AP Simons,' MD Lancé, 2,3 \\ YM Ganushchak,' O Bekers ${ }^{4}$ and PW Weerwind'
}

\begin{abstract}
Low-flow extracorporeal life support can be used for cardiopulmonary support of paediatric and neonatal patients and is also emerging as a therapy for patients suffering from exacerbation of chronic obstructive pulmonary disease. However, pump heating and haemolysis have proven to negatively affect the system and outcome. This in vitro study aimed at gaining insight into blood warming, pump heating and haemolysis related to the performance of a new low-flow centrifugal pump. Pump performance in the $400-1,500 \mathrm{ml} / \mathrm{min}$ flow range was modulated using small-sized dual-lumen catheters and freshly donated human blood. Measurements included plasma free haemoglobin, blood temperature, pump speed, pump pressure, blood flow and thermographic imaging. Blood warming $\left(\Delta \mathrm{T}_{\max }=0.5^{\circ} \mathrm{C}\right)$ had no relationship with pump performance or haemolysis $\left(R_{\max }^{2}=0.05\right)$. Pump performance-related parameters revealed no relevant relationships with haemolysis $\left(R_{\max }^{2}=0.36\right)$. Thermography showed no relevant heat zones in the pump $\left(T_{\max }=36^{\circ} \mathrm{C}\right)$. Concerning blood warming, pump heating and haemolysis, we deem the centrifugal pump applicable for low-flow extracorporeal circulation.
\end{abstract}

\section{Keywords}

centrifugal pump; extracorporeal life support; pump heating; haemolysis; normalized index of haemolysis

\section{Introduction}

Extracorporeal life support (ECLS) has proven a successful technique for providing cardiopulmonary assistance in adult patients, using supporting blood flows of 3-5 $1 / \mathrm{min} \cdot{ }^{1-3}$ Adapted towards a low-flow application using supporting blood flows of approximately 0.5 to 1.5 $1 / \mathrm{min}$, ECLS can be used for the support of paediatric and neonatal patients ${ }^{4-6}$ or as an emerging therapy for patients suffering from exacerbation of chronic obstructive pulmonary disease..$^{7-11}$

With centrifugal pump-based ECLS, the hydraulic resistance of small-size catheters and/or an increased patient demand can be compensated for by increasing the pump speed. ${ }^{12}$ Pump speed, however, is found to be an independent risk factor for haemolysis. ${ }^{6}$ Simply increasing pump speed may force the centrifugal pump to operate outside its best efficiency zone. ${ }^{12}$ Moreover, a study using early generation pumps has shown that increasing pump speed while the flow remains relatively low can result in unstable support flow and severe pump heating. ${ }^{13}$ In contrast, a recently introduced, newgeneration, low-flow, dedicated centrifugal pump has

'Department of Cardiothoracic Surgery, Maastricht University Medical Centre and Cardiovascular Research Institute Maastricht, Maastricht, the Netherlands

2Department of Anesthesiology and Pain Treatment, Maastricht University Medical Centre, Maastricht, the Netherlands

${ }^{3}$ Department of Intensive Care Medicine, Maastricht University Medical Centre, Maastricht, the Netherlands

${ }^{4}$ Department of Clinical Chemistry, Maastricht University Medical

Centre, Maastricht, the Netherlands

Corresponding author:

Dr. Antoine P. Simons, Department of Cardiothoracic Surgery,

Maastricht University Medical Centre, P.O. Box 5800, 6202 AZ

Maastricht, the Netherlands.

Email: antoinepsimons@maastrichtuniversity.nl

Presented at the 37th annual seminar of The American Academy of Cardiovascular Perfusion, Savannah, Georgia, USA 4-7 February 2016 


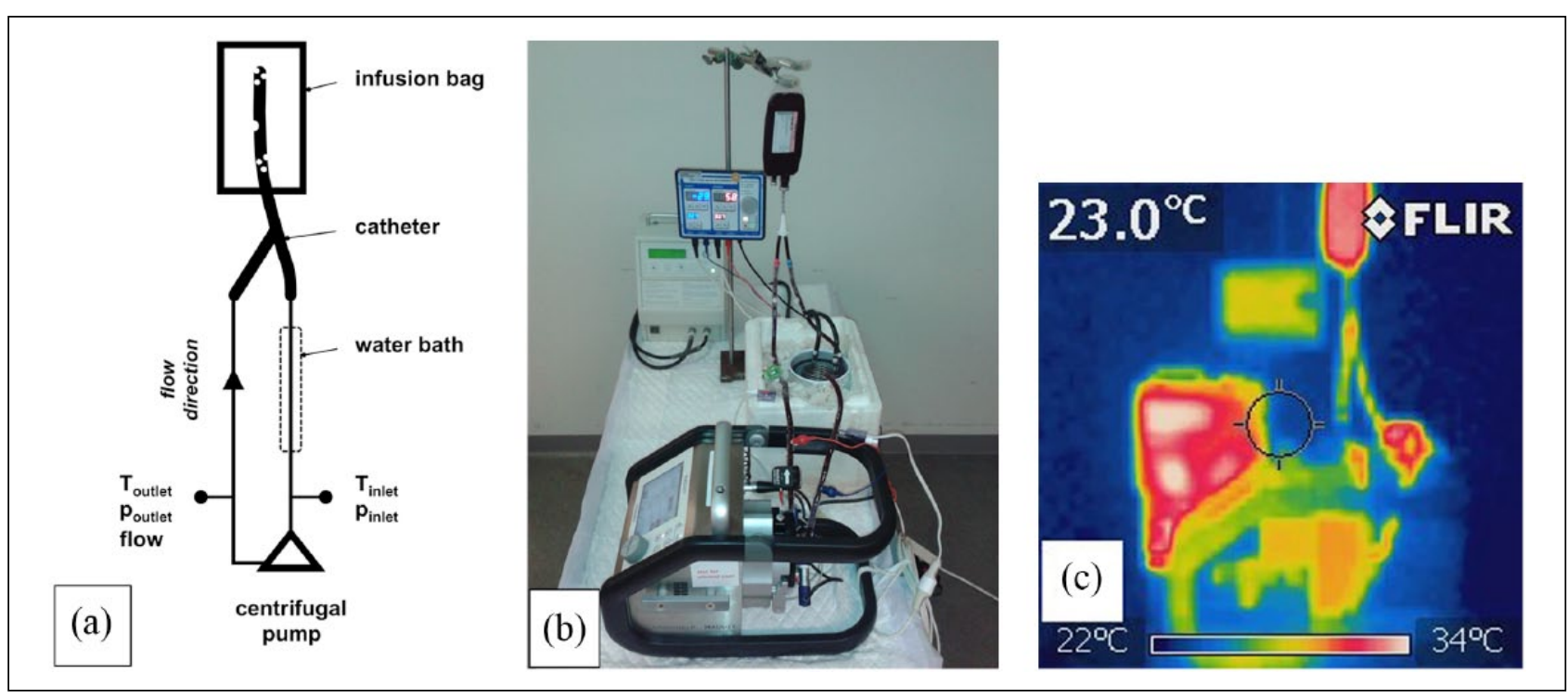

Figure I. Schematic representation (left), photograph (middle) and thermographic image (right) of the mock circulation which allowed for the measurement of flow and both temperature $(T)$ and pressure $(p)$ at the inlet and outlet of the pump. The warmest areas visible are the large housing of the heater unit and the infusion bag containing approximately $200 \mathrm{ml}$ of blood. The average temperature within the circular area covered by the crosshair is given in the upper left corner, i.e. in this example $23.0^{\circ} \mathrm{C}$.

demonstrated excellent hydrodynamic stability. ${ }^{14}$ Data on performance of that pump in relation to blood warming, pump heating and haemolysis, however, have, to the best of our knowledge, not yet been reported.

The aim of this in vitro study using freshly donated human blood was to gain insight into blood warming, pump heating and haemolysis related to the performance of a new low-flow dedicated centrifugal pump.

\section{Materials and Methods}

The study was approved by the medical ethical committee of the Maastricht University Medical Centre. Written informed consent was obtained from all blood donors. The study was registered at the Dutch Trial Register, trial number NTR4874.

\section{Mock circulation}

A mock circulation was built to investigate blood warming, pump heating and haemolysis in relationship to pump performance as modulated by catheter design and size. The mock circulation (Figure 1) consisted of a double-lumen catheter inserted into a $100 \mathrm{ml}$ infusion bag, $1 / 4$ inch polyvinyl chloride tubing (Medtronic, Minneapolis, MN, USA) and a low-flow centrifugal pump (Rotassist 2.8) with drive adapter (sn: 90425123) and CardioHelp drive unit (sn: 90410012, firmware ver. 3.04.02, Maquet Cardiopulmonary AG, Hirrlingen, Germany). The circuit had a total volume of approximately $300 \mathrm{ml}$. The tubing was guided through a water bath kept at $37^{\circ} \mathrm{C}$ using a heater unit (Hypohyperthermia model CF1, GranuLab International B.V., Amersfoort, the Netherlands). Flow was measured using a $1 / 4$ inch ultrasound flow probe (sn: 90045055) that came with the pump drive unit. Pressures and blood temperatures were measured in-line at the inlet and outlet of the centrifugal pump using disposable pressure transducers (PX604, TruWave, Edwards Lifesciences, Irvine, CA, USA; zeroed towards atmosphere) and temperature probes (Capiox Luer Thermistor, Terumo Corp., Tokyo, Japan), respectively. A custom-built data acquisition system (PASAQ, Instruments Development Engineering \& Evaluation, Maastricht University Medical Centre, Maastricht, the Netherlands) provided pressure and blood temperature read-out.

A calibrated thermographic camera (ThermaCAM SC2000, Flir Systems, Inc., Wilsonville, Oregon, USA) enabled visualisation of pump heating by recording surface temperature distribution of both centrifugal pump and drive unit. During each pump run, the water bath, tubing, infusion bag and catheter were covered with aluminium foil to reduce heat loss by radiation and to maintain circuit temperature. The drive unit, centrifugal pump and temperature sensors remained uncovered. The ambient temperature was $20^{\circ} \mathrm{C}$.

\section{Catheters}

Figure 2 shows four different small-size, doublelumen catheters, ranging from 13 to 18 French (4.3 to $6 \mathrm{~mm}$ ). Their varying hydraulic resistance was used to modulate pump performance in terms of pumping 


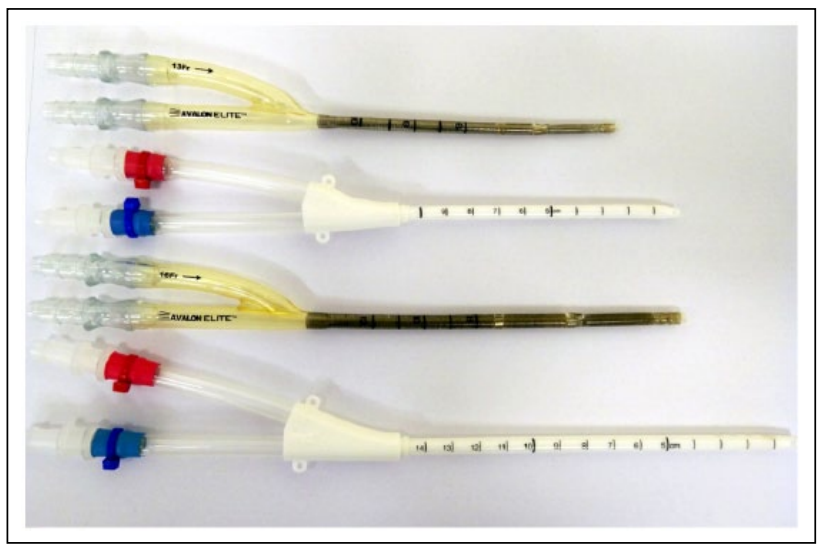

Figure 2. Double-lumen catheters of various sizes. From top to bottom: 13 French (Maquet), I5 French (OriGen, Biomedical, Austin, TX, USA), 16 French (Maquet) and 18 French (OriGen).

efficiency and pump head, with resultant blood warming and pump heating.

\section{Protocol}

For donation, approximately $250 \mathrm{ml}$ human whole blood was collected into a blood collection bag containing citrate solution (CompoFlex CPDA-1, Fresenius Kabi AG, Bad Homburg, Germany), according to institutional protocol for blood donation. Subsequently, the fully anticoagulated whole blood was diluted down to a haematocrit of $30 \%$ using sodium chloride $0.9 \%$. After mounting one of the four catheters, the circuit was primed using the diluted blood. Centrifugal pump speed (in rpm, rotations per minute) was adjusted to induce a flow rate of either $400 \mathrm{ml} / \mathrm{min}, 700 \mathrm{ml} / \mathrm{min}, 1,000$ $\mathrm{ml} / \mathrm{min}$ or $1,500 \mathrm{ml} / \mathrm{min}$ by using the mounted catheter as a resistance. Citrated blood samples were drawn from the circuit in duplicate after 5 minutes and after 6 hours of pump run. Samples were immediately centrifuged (3,000 rpm, 12 minutes, $\left.4^{\circ} \mathrm{C}\right)$, and sent to the laboratory for plasma free haemoglobin $\left(\mathrm{Hb}_{\text {free }}\right)$ assay. After 3 and 6 hours of the pump run, pump speed, pump flow rate, blood temperature and pressure read-outs were recorded. A thermographic image was taken after 6 hours. Each catheter size-flow rate combination was tested in triplicate and used single-donor blood and new sterile circuit tubing, tube connectors and infusion bag. The centrifugal pump and catheter were reused after being thoroughly rinsed by a $0.9 \% \mathrm{NaCl}$ solution and dried at atmosphere.

\section{Data processing and statistical analysis}

Average $\mathrm{Hb}_{\text {free }}$ levels were calculated for the two samples taken from the circuit after 5 minutes of pump run and after 6 hours of pump run. The difference in plasma free haemoglobin $\left(\Delta \mathrm{Hb}_{\text {free }}\right)$ was determined by subtracting the 6-hour average by the 5-minute average. A normalized index of haemolysis ${ }^{15}$ was calculated for each pump run and corrected for catheter size, according to

$$
\mathrm{NIH}_{\text {corrected }}=\frac{\Delta \mathrm{Hb}_{\text {free }} \cdot \mathrm{V}_{\text {total }} \cdot\left(1-\left(\frac{\mathrm{Hct}}{100}\right)\right) \cdot 100}{\Delta \mathrm{t} \cdot \text { flow } \cdot \text { catheter size }}
$$

in which $\mathrm{NIH}_{\text {corrected }}=$ catheter size-corrected normalized index of haemolysis in grams per 100 litre per French; $\Delta \mathrm{Hb}_{\text {free }}=$ difference in plasma free haemoglobin in grams per litre; $\mathrm{V}_{\text {total }}=$ total circulating volume in litres; Hct=haematocrit; $\Delta \mathrm{t}=$ time elapsed between the two samples in minutes; flow=pump flow rate in litres per minute; catheter size $=$ outer lumen catheter diameter in French.

Blood heating was represented by a blood temperature gradient, calculated by the subtraction of the blood temperature measured at the pump outlet by that measured at the inlet. The pump performance-related factors, pumping efficiency and pump head, were calculated by dividing pump flow by pump speed and by calculating the absolute pressure difference between the pump inlet and pump outlet, respectively. Blood temperature gradient, pumping efficiency and pump head were calculated twice for each test run: after 3 and 6 hours. Scatter plots were used to indicate a possible relationship between blood temperature gradient and pumping efficiency, pump head and $\mathrm{NIH}_{\text {corrected }}$. The proportion of variance was described by regression analysis. A Student $\mathrm{t}$-test was used to test for differences between the 3 hour and 6 hour groups of blood temperature gradient, pumping efficiency and pump head. Statistical analyses were performed using SPSS Statistics 22 (IBM Corp., Armonk, NY, USA). A p-value $<0.05$ was considered statistically significant.

\section{Results}

The largest catheter (18 French) with the maximum flow rate tested $(1.5 \mathrm{l} / \mathrm{min})$ required the highest pump speed of all the experiments $(3,600 \mathrm{rpm})$ whereas the smallest catheter (13 French) enabled a maximum flow rate of $400 \mathrm{ml} / \mathrm{min}$ at a pump speed of 2,300 rpm. Pumping efficiency ranged from $0.17 \mathrm{ml} /$ rotation to $0.43 \mathrm{ml} /$ rotation whereas the pump head varied from 41 $\mathrm{mmHg}$ to $322 \mathrm{mmHg}$. The highest measured blood temperature gradient between the pump inlet and pump outlet amounted to $0.5^{\circ} \mathrm{C}$. Figure 3 shows blood temperature data to reveal no clinically relevant relationships with respect to pump performance-related parameters, pumping efficiency $\left(\mathrm{R}_{3 \mathrm{~h}}^{2}=0.00, \mathrm{p}_{3 \mathrm{~h}}=0.94\right.$; 


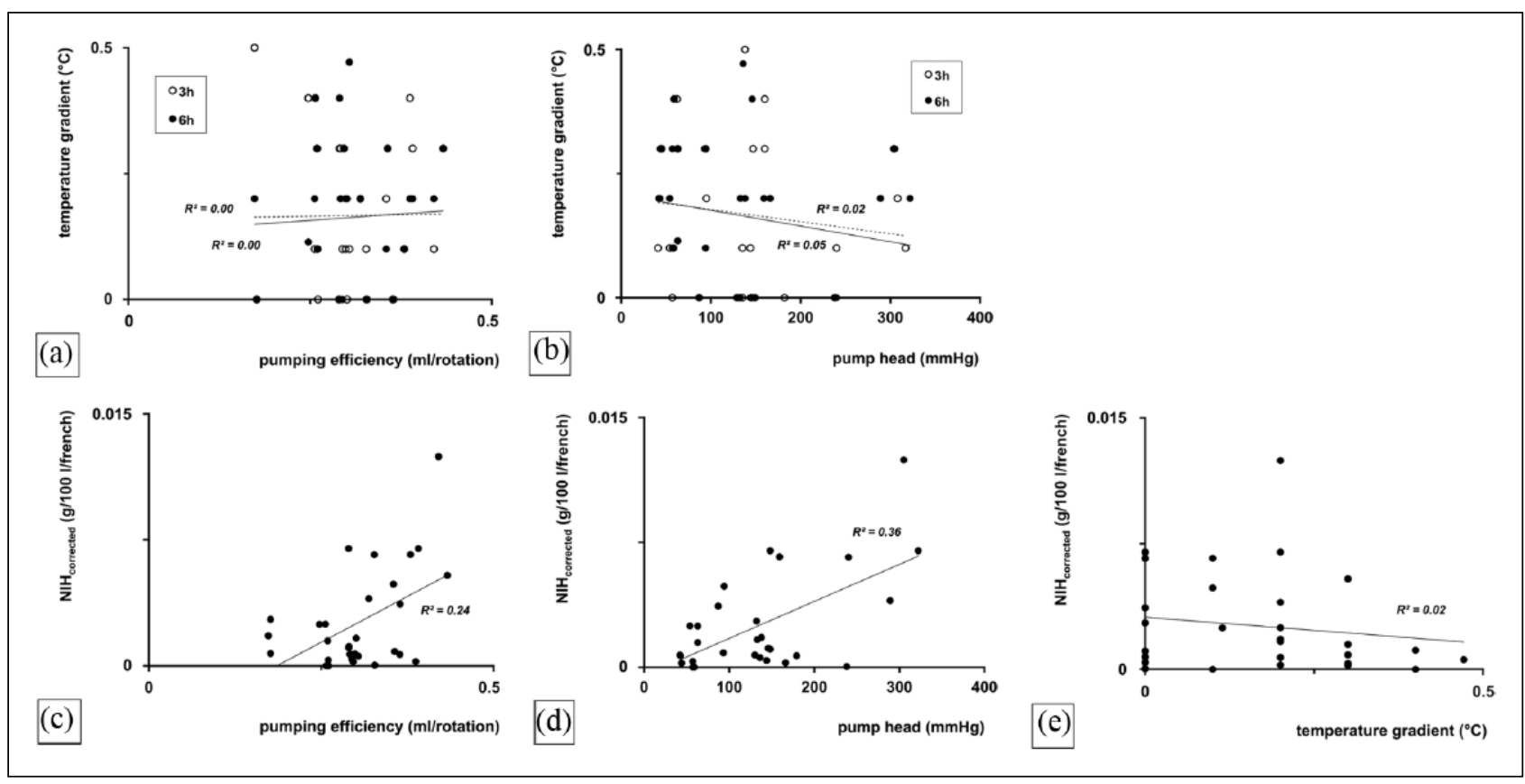

Figure 3. Scatterplot indicating relationships between pumping efficiency and blood temperature gradient (a), pump head and blood temperature gradient (b), pumping efficiency and catheter size-corrected normalized index of haemolysis $\left(\mathrm{NIH} \mathrm{H}_{\text {corrected }}\right)(\mathrm{c})$, pump head and $\mathrm{NIH}_{\text {corrected }}(\mathrm{d})$ and blood temperature gradient and $\mathrm{NIH}_{\text {corrected }}(\mathrm{e})$. Graphs a and b use the data of both 3 hours (dashed line) and 6 hours (continuous line) of pump run whereas graphs $c, d$ and e use the data of 6 hours of pump run.

$\left.\mathrm{R}^{2}{ }_{6 \mathrm{~h}}=0.00, \mathrm{p}_{6 \mathrm{~h}}=0.79\right)$ and pump head $\left(\mathrm{R}_{3 \mathrm{~h}}^{2}=0.02\right.$, $\left.\mathrm{p}_{3 \mathrm{~h}}=0.49 ; \mathrm{R}_{6 \mathrm{~h}}=0.05, \mathrm{p}_{6 \mathrm{~h}}=0.24\right)$. Neither pumping efficiency, nor pump head showed a relevant relationship to $\mathrm{NIH}_{\text {corrected }}\left(\mathrm{R}_{6 \mathrm{~h}}^{2}=0.24, \mathrm{p}_{6 \mathrm{~h}}=0.01\right.$ and $\mathrm{R}_{6 \mathrm{~h}}^{2}=0.36, \mathrm{p}_{6 \mathrm{~h}}=0.00$, respectively). No relationship was found between the blood temperature gradient and $\mathrm{NIH}_{\text {corrected }}\left(\mathrm{R}_{6 \mathrm{~h}}=0.02\right.$, $\mathrm{p}_{6 \mathrm{~h}}=0.41$ ). Furthermore, there were no significant differences between the 3 hour and 6 hour groups with respect to blood temperature gradient, pumping efficiency and pump head ( $\mathrm{p}>0.92$ for all).

Figure 4 shows 'normal' and thermographic imaging of the drive unit with the pump mounted onto the drive adapter. The thermographic images show the temperature distribution of the console, drive adapter and pump in the outer ranges of pumping efficiency and pump head. The warmest heat zones were found in the housing covering the impeller of the centrifugal pump and were near $36^{\circ} \mathrm{C}$, regardless of the pumping efficiency or pump head. The black housing of the drive adapter was warmest close to the pump volute and its temperature amounted to $29^{\circ} \mathrm{C}$ at maximum. The temperature of the drive unit did not exceed $30^{\circ} \mathrm{C}$.

\section{Discussion}

This study aimed at gaining insight into blood warming, pump heating and haemolysis in relation to the performance of a centrifugal pump for low-flow applications.
Blood warming and pump heating proved within safe ranges and showed no relationship with pump performance and red cell damage. In addition, there was no relationship between pump performance and red cell damage. No clinically relevant heat zones were found in the console, drive adapter or pump.

In contrast to full-blown extracorporeal life support (ECLS) that uses supporting blood flow rates of 3-6 $1 /$ min during refractory acute lung and/or cardiac failure, low-flow ECLS uses supporting blood flows of approximately 0.5 to $1.5 \mathrm{l} / \mathrm{min}$ and much smaller catheters. Low-flow ECLS can either be used for the support of paediatric and neonatal patients ${ }^{4-6}$ or as an emerging therapy for patients suffering from exacerbation of chronic obstructive pulmonary disease. ${ }^{7,9,16}$ This study on hydrodynamically simulated low-flow ECLS used a variety of dual-lumen catheters and blood flow rates ranging from 13 to 18 French and 0.4 to $1.5 \mathrm{l} / \mathrm{min}$, respectively. To overcome catheter flow resistance and achieve those supporting blood flow rates, centrifugal pump rotational speeds of up to $3,600 \mathrm{rpm}$ were required. Resulting pumping efficiencies, however, were relatively low, with a maximum value of $0.43 \mathrm{ml}$ per rotation (Figure 3). Under such pumping conditions, Ganushchak et al. demonstrated support instability and severe heating of the pump, its surrounding components and the pumped fluid ${ }^{13}$ whereas Takami et al. demonstrated loss in pumping power. ${ }^{17}$ Our data on varying pumping conditions, however, did not show 

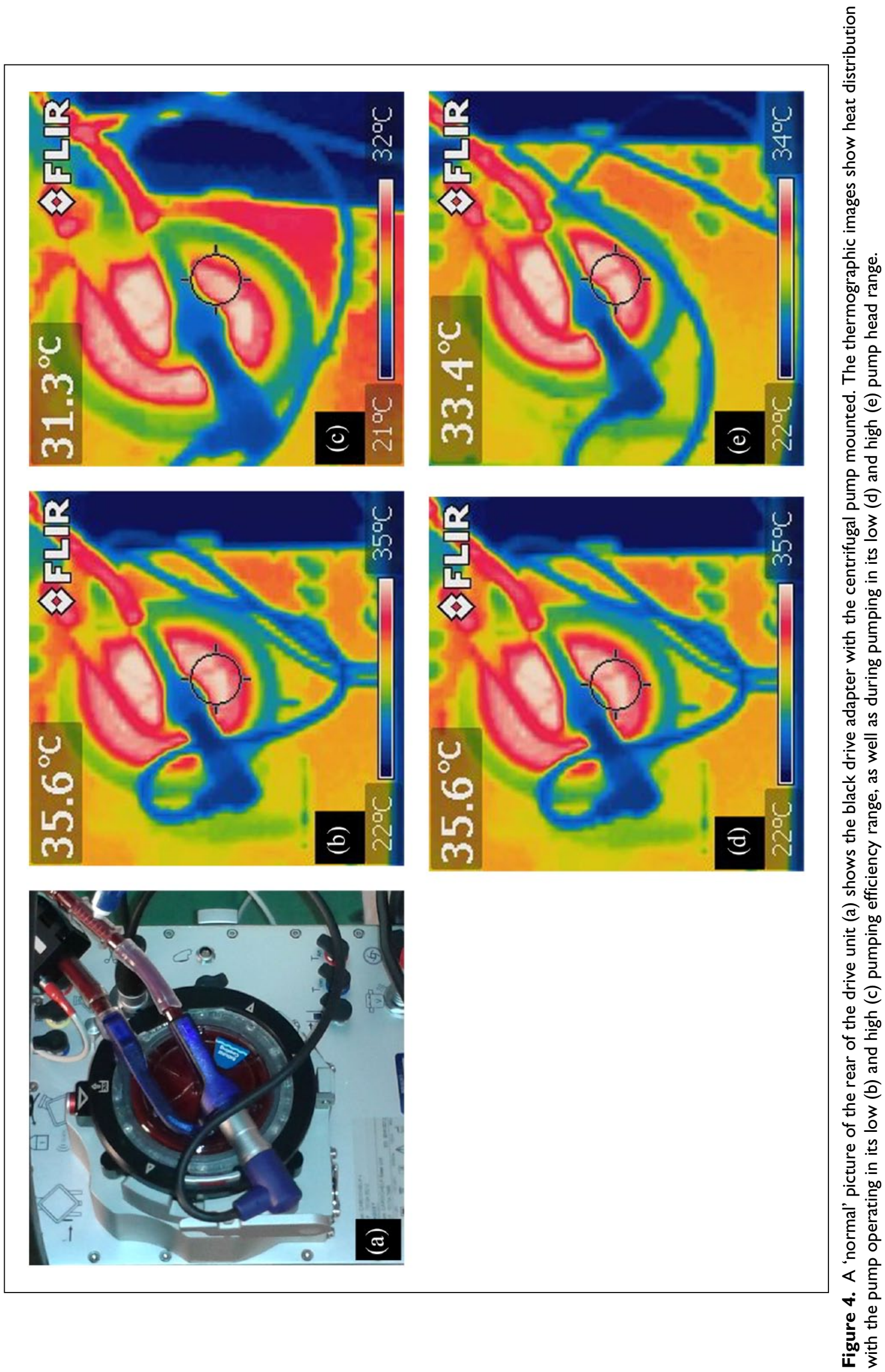
any relevant heating, neither of the pump nor of the drive adapter, console or the blood being pumped. Moreover, a previous study on the current low-flow pump with respect to hydraulic performance showed excellent support stability. ${ }^{14}$ An explanation for those contrasting results may be found in pump design. The pumps used by Ganushchak et al. were of a much older generation and originally intended for high-flow applications like cardiopulmonary bypass. Moreover, they featured completely different designs, using either metal bearings with the risk of running hot or plastic shaft sealing risking leakage when worn off whereas others required sufficient pump flow to achieve adequate motor cooling. The low-flow pump used in this study, in contrast, contains a low-friction, fluid-submersed, point bearing without shaft sealing. Furthermore, as in fully levitated pumps, it uses static coils for both impeller stabilization and driving.

Next to a lowered burden for the initiation of lowflow ECLS, small-sized catheters offer the advantage of improved patient comfort and easier access to bedsite physiotherapy in the pursuit of maintaining or regaining physical fitness. Several studies have investigated the implementation of low-flow applications of ECLS using relatively small catheters. Batchinsky et al. and Karagiannidis et al., in pre-clinical studies, applied blood flows of $0.5 \mathrm{l} / \mathrm{min}$ using 15.5 French dual-lumen catheters ${ }^{7}$ and blood flow rates of 0.3 to $1.0 \mathrm{l} / \mathrm{min}$ using a 19 French dual-lumen catheter, ${ }^{18}$ respectively. Next to those pre-clinical investigations on low-flow ECLS, several clinical studies have been reported. Burki et al. used 15.5 French dual-lumen catheters with supporting flows of $0.41 / \mathrm{min}^{9}$ and Mani et al. reported blood flow rates of up to $0.61 / \mathrm{min}$ when using the same catheter size. ${ }^{19}$ Sharma et al. supported patients, using pump flow rates of $0.51 / \mathrm{min}$ and dual-lumen catheters ranging from 12 to 24 French in size. ${ }^{16}$ Unfortunately, and in contrast to our study, none of those studies provided data on pump rotational speed, hence, rendering a direct data comparison regarding pumping efficiency among studies impossible. However, since our study applied a wide range of both catheter sizes and low-flow blood flow rates, it is most likely that the pumping conditions applied in both pre-clinical and clinical studies mentioned above are comparable with the pumping efficiency data of the current study.

The studies of Batchinsky, Burki and Mani included blood cell damage in terms of haemolysis. ${ }^{7,9,19}$ In contrast to Burki et al. and Mani et al. who used human blood, Batchinsky et al. used porcine blood, which shows a lower osmotic fragility. ${ }^{20}$ Nevertheless, none of the three studies could demonstrate any relevant red cell damage. Lou et al., in another study, searched for risk factors of haemolysis in pediatric ECLS patients being supported at an estimated pumping efficiency of $0.4 \mathrm{ml} /$ rotation. They found pump speed to be an independent risk factor for the occurrence of haemolysis. ${ }^{6}$ In contrast to those studies quantifying absolute plasma free haemoglobin levels as an outcome measure, our study calculated relative haemolysis expressed by the $\mathrm{NIH}$ and searched for a linkage with the centrifugal pump. We found no significant relationship between $\mathrm{NIH}$ and the pump-related parameters pumping efficiency, pump head and fluid warming. Based on the promising results of this experimental study and taking into account the results from our previous study on hydrodynamic pump performance, ${ }^{14}$ this new low-flow dedicated centrifugal pump can be considered for lowflow ECLS.

\section{Conclusion}

With no relevant heat zones found in the console, drive adapter or pump and with no meaningful relationships among pump performance, blood warming and haemolysis, we deem the Rotassist 2.8 centrifugal pump applicable for low-flow extracorporeal circulation.

\section{Acknowledgements}

The authors would like to gratefully acknowledge Maquet Netherlands B.V. and Medtronic Netherlands for providing free samples and Mr. Thomissen, Mss. de Jong, Mrs. ObenClaes and Mss. Kloosterman for their technical support.

\section{Declaration of Conflicting Interests}

The authors declared no potential conflicts of interest with respect to the research, authorship and/or publication of this article.

\section{Funding}

The authors received no financial support for the research, authorship and/or publication of this article.

\section{References}

1. Bartlett RH, Roloff DW, Custer JR, et al. Extracorporeal life support: the University of Michigan experience. JAMA 2000; 283: 904-908.

2. Chung SY, Sheu JJ, Lin YJ, et al. Outcome of patients with profound cardiogenic shock after cardiopulmonary resuscitation and prompt extracorporeal membrane oxygenation support. A single-center observational study. Circ J 2012; 76: 1385-1392.

3. Peek GJ, Mugford M, Tiruvoipati R, et al. Efficacy and economic assessment of conventional ventilatory support versus extracorporeal membrane oxygenation for severe adult respiratory failure (CESAR): a multicentre randomised controlled trial. Lancet 2009; 374: 1351-1363.

4. Pettignano R, Fortenberry JD, Heard ML, et al. Primary use of the venovenous approach for extracorporeal 
membrane oxygenation in pediatric acute respiratory failure. Pediatr Crit Care Med 2003; 4: 291-298.

5. Paden ML, Conrad SA, Rycus PT, et al. Extracorporeal Life Support Organization Registry Report 2012. ASAIO J 2013; 59: 202-210.

6. Lou S, MacLaren G, Best D, et al. Hemolysis in pediatric patients receiving centrifugal-pump extracorporeal membrane oxygenation: prevalence, risk factors, and outcomes. Crit Care Med 2014; 42: 1213-1220.

7. Batchinsky AI, Jordan BS, Regn D, et al. Respiratory dialysis: reduction in dependence on mechanical ventilation by venovenous extracorporeal $\mathrm{CO}_{2}$ removal. Crit Care Med 2011; 39: 1382-1387.

8. Terragni P, Maiolo G, Ranieri VM. Role and potentials of low-flow $\mathrm{CO}_{2}$ removal system in mechanical ventilation. Curr Opin Crit Care 2012; 18: 93-98.

9. Burki NK, Mani RK, Herth FJF, et al. A novel extracorporeal $\mathrm{CO}_{2}$ removal system: results of a pilot study of hypercapnic respiratory failure in patients with COPD. CHEST 2013; 143: 678-686.

10. Gattinoni L, Pesenti A, Mascheroni D, et al. Lowfrequency positive-pressure ventilation with extracorporeal $\mathrm{CO}_{2}$ removal in severe acute respiratory failure. JAMA 1986; 256: 881-886.

11. Pesenti A, Pelizzola A, Mascheroni D, et al. Low frequency positive pressure ventilation with extracorporeal $\mathrm{CO}_{2}$ removal (LEPPV-ECCO ${ }_{2} \mathrm{R}$ ) in acute respiratory failure (ARF): technique. Trans Am Soc Artif Intern Organs 1981; 27: 263-266.
12. Bachus L, Custodio A. Know and understand centrifugal pumps. Elsevier, Oxford. 2003.

13. Ganushchak YM, van Marken Lichtenbelt W, van der Nagel T, et al. Hydrodynamic performance and heat generation by centrifugal pumps. Perfusion 2006; 21: 373-379.

14. Simons AP, Martens EGHJ, Ganushchak YM. Centrifugal pump performance during low-flow extracorporeal $\mathrm{CO}_{2}$ removal; safety considerations. Perfusion 2015; 30: 17-23.

15. American Society for Testing and Materials (ASTM) F1841-97. Standard practice for assessment of hemolysis in continuous flow blood pumps; Book of standards. 2005.

16. Sharma AS, Weerwind PW, Strauch U, et al. Applying a low-flow $\mathrm{CO}_{2}$ removal device in severe acute hypercapnic respiratory failure. Perfusion 2016; 31: 149-155.

17. Takami Y, Nakazawa T, Makinouchi K, et al. Pump power loss and heat generation in a pivot bearing-supported Gyro centrifugal pump (C1E3). Artif Organs 1996; 20: 794-797.

18. Karagiannidis C, Kampe KA, Sipmann FS, et al. Venovenous extracorporeal $\mathrm{CO}_{2}$ removal for the treatment of severe respiratory acidosis: pathophysiological and technical considerations. Crit Care 2014; 18: R124.

19. Mani RK, Schmidt W, Lund LW, et al. Respiratory dialysis for avoidance of intubation in acute exacerbation of COPD. ASAIO J 2013; 59: 675-678.

20. Matsuzawa T, Ikarashi Y. Haemolysis of various mammalian erythrocytes in sodium chloride, glucose and phosphate-buffer solutions. Lab Anim 1979; 13: 329-331. 


\title{
Discussion: Blood warming, pump heating and haemolysis in low-flow extracorporeal life support; an in vitro study using freshly donated human blood
}

\author{
Presenter, Antoine Simons
}

CO-MODERATOR JOSEPH DEPTULA (Omaha, Nebraska): With the catheter that was collapsing as you described, did you use a new catheter or did you reuse the catheters?

DR. ANTOINE SIMONS (Maastricht, the Netherlands): The catheters we used are expensive so we had to reuse them. We cleaned them and rinsed them thoroughly. For the catheter that collapsed under the extreme experiment after two minutes, we just rinsed it thor- oughly and then held it under some hot tap water to get it back into shape. Once it cooled down, one could tap it on the table again because it was hard again. We were very surprised that this catheter was so rigid and hard once it cooled down. You could not even squeeze it, which was so remarkable. We had just seen this catheter collapse in the circuit and the bag. It was so rubbery. We were very surprised about that finding.

This discussion is taken from the dialogue that followed the presentation of the previous paper at the 37th Annual Seminar of the American Academy of Cardiovascular Perfusion. Although the paper has been through Perfusion's stringent peer-review process, the discussion is a transcript of the dialogue, edited for clarity, and the views expressed in the discussion are those of the commentators and do not necessarily represent, and should not be attributed to, the journal Perfusion, the Editors, authors or the Publisher, SAGE. 